\title{
КОЛОНКА ГЛАВНОГО РЕДАКТОРА
}

DOI: https://doi.org/10.15688/lc.jvolsu.2021.2.1

UDC 351.74

LBC 67.401 .132

\section{THE COORDINATION OF THE LAW ENFORCEMENT ACTIVITIES IN THE FIGHT AGAINST CRIME SAFEGUARDING THE NATIONAL SECURITY OF THE RUSSIAN FEDERATION}

\author{
Agnessa O. Inshakova \\ Volgograd State University, Volgograd, Russian Federation
}

\begin{abstract}
Annotation. The introductory paper by the editor-in-chief of the next issue of "Legal Concept $=$ The Legal paradigm" is a brief justification of the relevance of the stated topic - "The modern methodology for the coordination of criminal procedure activities of the law enforcement agencies", and also accumulates the quintessence of the knowledge presented in the scientific papers of the heading "The main topic of the issue" and the research results of the coordination of the law enforcement agencies in the fight against crime. The editorial board of the journal believes that the coordination activity being studied from the standpoint of criminal procedure science is of particular interest in the context of eliminating threats to the national security of the Russian Federation by legal methods and means. The author substantiates the urgency of the problem of ensuring and improving the interaction of the law enforcement agencies in the fight against crime, primarily, the complex criminal situation in the country. It is noted that the participation of various law enforcement agencies in the fight against crime determines the need for the systematic coordination of their efforts. The coordination of the law enforcement activities to combat crime in connection with this fact is one of the central functions of the prosecutor's office and at the same time a mechanism to ensure the guarantee of such coordination, a tool to increase the efficiency of countering crime. The paper analyzes the scientific and practical significance of the papers that make up the heading "The main topic of the issue" and are characterized by both the theoretical and applied value. The general orientation of the papers and their distinctive features as original, creative research developments distinguished by the scientific novelty is described briefly. The multi-aspect nature of the stated topic is justified through the variety of questions formulated by the authors of the main topic. The author hopes that the collected thematic papers will be especially useful while improving the law enforcement practice in the fight against crime.

Key words: law enforcement agencies, combating crime, threats to national security, extremism, pre-trial proceedings, coordination of activities, unjustified criminal prosecution, forensic examination, juvenile delinquency, prevention of juvenile delinquency, professional qualities of investigative officers.
\end{abstract}

Citation. Inshakova A.O. The Coordination of the Law Enforcement Activities in the Fight Against Crime Safeguarding the National Security of the Russian Federation. Legal Concept = Pravovaya paradigma, 2021, vol. 20, no. 2, pp. 6-11. (in Russian). DOI: https://doi.org/10.15688/lc.jvolsu.2021.2.1

УДК 351.74

ББК 67.401 .132

КООРДИНАЦИЯ ДЕЯТЕЛЬНОСТИ ПРАВООХРАНИТЕЛЬНЫХ ОРГАНОВ ПО БОРЬБЕ С ПРЕСТУПНОСТЬЮ НА СТРАЖЕ НАЦИОНАЛЬНОЙ БЕЗОПАСНОСТИ РФ

\author{
Агнесса Олеговна Иншакова
}

Волгоградский государственный университет, г. Волгоград, Российская Федерация

Правовая парадигма. 2021. Т. 20. № 2 
Аннотация. Вводная статья главного редактора очередного номера «Legal Concept = Правовая парадигма» представляет собой краткое обоснование актуальности заявленной темы - «Современная методология координации уголовно-процессуальной деятельности правоохранительных органов», а также аккумулирует в себе квинтэссенцию представленных в научных статьях рубрики «Главная тема номера» знаний и полученных результатов исследований, посвященных координации деятельности правоохранительных органов по борьбе с преступностью. Редакционная коллегия журнала полагает, что исследуемая координационная деятельность с позиции уголовно-процессуальной науки представляет особый интерес в контексте устранения правовыми методами и средствами угроз национальной безопасности РФ. Автор обосновывает актуальность проблемы обеспечения и совершенствования взаимодействия правоохранительных органов по борьбе с преступностью, прежде всего, сложной криминогенной обстановкой в стране. Отмечается, что участие в деятельности по борьбе с преступностью различных силовых ведомств предопределяет необходимость системного согласования их усилий. Координация деятельности правоохранительных органов по борьбе с преступностью во взаимосвязи с данным фактом выступает одной из центральных функций прокуратуры и одновременно механизмом обеспечения гарантии такого согласования, инструментом повышения эффективности противостояния преступности. Анализируется научная и практическая значимость статей, составивших рубрику «Главная тема номера» и характеризующихся как теоретической, так и прикладной ценностью. Дается краткое описание общей направленности статей и их отличительных особенностей в качестве оригинальных, творческих исследовательских разработок, отличающихся научной новизной. Многоаспектность заявленной темы обосновывается через разнообразие сформулированных авторами главной темы вопросов. Автор выражает надежду на то, что собранные тематические статьи будут особенно полезны в процессе совершенствования правоприменительной практики по борьбе с преступностью.

Ключевые слова: правоохранительные органы, борьба с преступностью, угрозы национальной безопасности, экстремизм, досудебное производство, координация деятельности, необоснованное уголовное преследование, судебно-медицинская экспертиза, подростковая преступность, профилактика преступности несовершеннолетних, профессиональные качества следственных работников.

Цитирование. Иншакова А. О. Координация деятельности правоохранительных органов по борьбе с преступностью на страже национальной безопасности РФ // Legal Concept = Правовая парадигма. - 2021. T. 20, № 2. - C. 6-11. - DOI: https://doi.org/10.15688/lc.jvolsu.2021.2.1

Главная тема очередного номера юридического журнала Волгоградского государственного университета «Legal Concept $=$ Правовая парадигма» посвящена координации деятельности правоохранительных органов по борьбе с преступностью, представляющей одну из серьезных угроз национальной безопасности РФ.

Актуальность проблемы обеспечения и совершенствования взаимодействия правоохранительных органов по борьбе с преступностью в современных условиях, адекватных состоянию и тенденциям в этой сфере, неоспорима и обусловлена сложной криминогенной обстановкой в стране. Участие в деятельности по борьбе с преступностью различных силовых ведомств предопределяет необходимость системного согласования их усилий. Координация деятельности правоохранительных органов по борьбе с преступностью во взаимосвязи с данным фактом выступает одной из центральных функций прокуратуры и одновременно механизмом обеспечения гарантии такого согласования, инст- рументом повышения эффективности противостояния преступности.

В рубрику «Главная тема номера» вошли статьи не только теоретического, но и прикладного характера. Так, авторами опубликованных работ выступили не только российские ученые в области уголовного процесса, криминалистики, теории и истории права и государства, политологии, а также практические работники, без которых невозможна координация деятельности правоохранительных органов по борьбе с преступностью (сотрудник полиции, мировой судья и судмедэксперт). Три из двенадцати статей были написаны в ходе реализации гранта РФФИ № 20-011-00688 (А) «Модель профилактики экстремизма в молодежной среде: интеграция деятельности гражданских ассоциаций и силовых структур в контексте правовой социализации», участниками которого являются сотрудники кафедры уголовного процесса Института права Волгоградского государственного университета. Среди них исследования на тему: «Взаимодействие следователя с органом дознания в ходе рас- 
следования преступлений по делам об экстремизме: проблемы и пути решения» и «Совершенствование деятельности прокуратуры по предупреждению преступлений экстремистской направленности среди несовершеннолетних». Научный интерес представляет статья «Взаимодействие следователя с органом дознания в ходе расследования преступлений по делам об экстремизме: проблемы и пути решения», подготовленная кандидатом юридических наук, доцентом кафедры уголовного процесса и криминалистики Волгоградского государственного университета В.М. Шинкаруком, кандидатом юридических наук, доцентом, начальником кафедры предварительного расследования учебно-научного комплекса по предварительному следствию в органах внутренних дел Волгоградской академии МВД России С.Ю. Бирюковым и доктором юридических наук, профессором, доцентом кафедры криминалистики учебно-научного комплекса по предварительному следствию в органах внутренних дел Волгоградской академии МВД России А.П. Резваном. Работа посвящена анализу отдельных проблем, возникающих в результате организации и поддержания на должном уровне взаимодействия между органом следствия и иными субъектами расследования для обеспечения оперативного и всестороннего установления всех обстоятельств, подлежащих доказыванию. В процессе научного дискурса ученым удалось выявить имеющиеся проблемы, детерминированные изменениями уголовно-процессуального законодательства и оперативноследственной практикой, предложить пути по их преодолению в целях информирования обучающихся по направлению подготовки «Юриспруденция», педагогических работников юридических вузов, а также практических работников для более полного понимания особенностей расследования преступлений экстремистской направленности.

В контексте обозначенной проблематики научной новизной отличается статья «Совершенствование деятельности прокуратуры по предупреждению преступлений экстремистской направленности среди несовершеннолетних», подготовленной кандидатом политических наук, доцентом кафедры уголовного процесса и криминалистики Волгоградского государственного университета П.П. Фантровым, профессором кафедры уголовного права, уголовного процесса и криминалистики Российского университета транспорта (РУТ (МИИТ)), доктором юридических наук, профессором М.В. Бобовкиным, а также помощником прокурора Центрального района г. Волгограда С.А. Меденцовым. В результате проведенного исследования авторами статьи выявлены основные проблемы в деятельности прокуратуры по предупреждению экстремистской преступности несовершеннолетних (формализм, отсутствие индивидуального подхода профилактической работы, проблемы межведомственного взаимодействия). В статье обоснована необходимость совершенствования правового статуса прокурора как координатора и одного из ключевых субъектов профилактики правонарушений экстремистского толка.

Статья доктора юридических наук, профессора, заведующей кафедрой уголовного процесса Саратовской государственной юридической академии Н.С. Мановой на тему «Роль прокурора в координации деятельности органов дознания и предварительного следствия по осуществлению уголовного преследования» также выполена в рамках гранта и посвящена оценке деятельности одного из самых влиятельных субъектов в системе правоохранительных органов - прокурора. Проблемы, затронутые в этой работе, весьма актуальны в связи с необходимостью выявления ошибок при реформировании процессуального положения прокурора в досудебном производстве, определении существенных компонентов в реальной модели деятельности прокурора, которые не были учтены законодателем.

Схожей тематике посвящена статья кандидата юридических наук, профессора, профессора кафедры уголовного процесса и криминалистики А.П. Кругликова - «Прокурор - координатор правоохранительной деятельности по борьбе с преступностью». В процессе проведенного исследования ученый обосновал руководящую роль прокурора в координации правоохранительной деятельности, выявил положительный опыт и недостатки ее осуществления.

В научной статье «Взаимодействие следователя, руководителя следственного орга- 
на и прокурора при возбуждении и осуществлении уголовного преследования», подготовленной доктором юридических наук, профессором, профессором кафедры уголовного процесса и криминалистики Юридического института Самарского национального исследовательского университета имени академика С.П. Королева В.А. Лазаревой, выявлены причины недостаточно эффективного взаимодействия органов уголовного преследования и предложены способы их устранения. Автор справедливо отмечает, что необходимость повышения эффективности взаимодействия следователя, руководителя следственного органа и прокурора требует серьезного пересмотра ряда норм УПК РФ.

Пониманию особенностей взаимодействия суда с должностными лицами стороны обвинения, обладающими властными полномочиями на стадиях возбуждения уголовного дела и предварительного расследования, служит научное исследование «Особенности взаимодействия прокурора, органов следствия и суда в досудебном производстве по уголовному делу», написанное доктором юридических наук, профессором, профессором кафедры уголовного процесса Саратовской государственной юридической академии Ю.В. Францифоровым, кандидатом юридических наук, доцентом, заведующей кафедрой уголовного процесса и криминалистики Волгоградского государственного университета Н.А. Соловьевой и студентом института права Волгоградского государственного университета В.В. Шинкаруком. Исследовательским коллективом авторов предложены рекомендации по повышению эффективности взаимодействия отдельных участников стороны обвинения и суда в досудебном производстве по уголовным делам, например, активизации сотрудничества субъектов расследования, прокурора и суда, направленной на защиту прав лиц, потерпевших от преступления, и обеспечение прав личности, подвергшейся необоснованному уголовному преследованию.

Судебно-психологический аспект темы рубрики журнала затронут в статье «Организационные и тактические аспекты взаимодействия следователя и эксперта при назначении и производстве судебно-медицинской экспер- тизы», подготовленной заведующим отделением судебно-медицинской экспертизы (г. Волгоград) филиала № 2 ФГКУ «111 Главный государственный центр судебно-медицинских и криминалистических экспертиз» Министерства обороны Российской Федерации, кандидатом медицинских наук, доцентом А.А. Меденцовым, доктором юридических наук, профессором, профессором кафедры судебной экспертизы и физического материаловедения Волгоградского государственного университета В.А. Ручкиным, старшим преподавателем кафедры криминалистической техники Волгоградской академии МВД России И.Т. Захарья. Результатом проведенного коллективом авторов исследования стали разработанные практико-ориентированные рекомендации по улучшению взаимодействия следователя и эксперта при назначении и производстве судебно-медицинской экспертизы.

Практическую ценность представляет научная статья «Координация деятельности правоохранительных органов по профилактике и раскрытию преступлений, совершаемых несовершеннолетними», выполненная авторами, имеющими опыт работы в правоохранительных органах свыше 15 лет, в следующем составе: полковник полиции в отставке, кандидат юридических наук, доцент кафедры уголовного процесса и криминалистики Волгоградского государственного университета П.П. Мураев; начальник отделения по раскрытию тяжких и особо тяжких преступлений против личности отдела уголовного розыска Управления МВД России по г. Волгограду Р.П. Мураев. В представленной работе они охарактеризовали существующие проблемы подростковой преступности, выявили перспективные направления профилактики преступности несовершеннолетних, дали оценку результатам борьбы с молодежной преступностью на территории Волгоградской области за 2020 год.

Проблемы реализации процессуальных взаимоотношений прокурора и следователя по избранию меры пресечения в судебно-контрольном производстве (на примере заключения под стражу) в своей статье рассмотрели старший преподаватель кафедры уголовного процесса и криминалистики Волгоградского государственного университета Д.Г. Каххоров, 
доктор юридических наук, профессор кафедры теории и истории права и государства Волгоградского государственного университета В.М. Абдрашитов и студентка института права Волгоградского государственного университета В.Д. Гаврилова. Исследовательским коллективом предложена процессуальная модель взаимодействия прокурора и дознавателя в ходе судебно-контрольного производства, которая может быть применена в регулировании отношения между прокурором и следователем при рассмотрении вопроса об избрании меры пресечения в виде заключения под стражу.

Интересным и нестандартным исследовательским подходом характеризуется статья «Установление близких родственников умершего подозреваемого или обвиняемого при производстве по уголовному делу: проблемы правовой регламентации и взаимодействия», авторами которой являются: кандидат юридических наук, доцент кафедры предварительного расследования учебно-научного комплекса по предварительному следствию в органах внутренних дел Волгоградской академии МВД России К.А. Трифонова; доктор юридических наук, профессор, профессор кафедры предварительного расследования учебно-научного комплекса по предварительному следствию в органах внутренних дел М.А. Шматов; доцент кафедры уголовного процесса и криминалистики Волгоградского государственного университета, кандидат юридических наук, доцент, мировой судья судебного участка № 47 Светлоярского судебного района Волгоградской области В.Н. Перекрестов. В ходе проведенного исследования они предлагают совершенствовать правовое положение умершего лица, которому еще не придан статус подозреваемого или обвиняемого, но в отношении которого осуществлялось уголовное преследование. Кроме того, ими охарактеризована деятельность органа расследования по установлению близких родственников с целью выяснения их мнения по поводу принимаемого решения в порядке п. 4 ч. 1 ст. 24 УПК РФ и приведены рекомендации по организации взаимодействия, направленного на установление обозначенных участников уголовного процесса.
Слаженное взаимодействие правоохранительных органов по борьбе с преступностью во многом обусловлено квалификацией сотрудников координационной деятельности. Поэтому статья, посвященная подготовке и повышению квалификации следственных работников, являющихся важной составляющей кадровой работы правоохранительных органов Российской Федерации, органично вписывается в тематическую канву главной рубрики. Работа «Некоторые особенности повышения квалификации следователей правоохранительных органов» подготовлена старшим преподавателем кафедры криминалистики Екатеринбургского филиала ФГКОУ ВО «Московская академия Следственного комитета Российской Федерации» А.К. Шеметовым и доктором юридических наук, доцентом кафедры уголовного права, уголовного процесса и криминалистики Московского государственного института международных отношений (университет) МИД России В.Ф. Васюковым. По результатам проведенного исследования авторам статьи удалось определить ряд особенностей развития и формирования профессиональных качеств следственных работников, их эффективного развития в контексте повышения квалификации, выявить и охарактеризовать направления взаимодействия со специалистами из других областей для разработки и внедрения в практику рекомендаций по совершенствованию деятельности ведомственных образовательных учреждений.

Название статьи, подготовленной Е.С. Азаровой и В.И. Внуковым - кандидатами юридических наук, доцентами кафедры уголовного процесса и криминалистики Волгоградского государственного университета, полностью отвечает тематической рубрике журнала. На основании правового анализа ими раскрывается содержание координационной деятельности через призму эффективных согласованных действий в борьбе с преступностью.

Разнообразие поднимаемых вопросов как нельзя лучше показывает многоаспектность заявленной темы. Редакционная коллегия журнала надеется, что собранные тематические статьи будут полезны в процессе совершенствования правоприменительной практики по борьбе с преступностью. 
А.О. Иншакова. Координация деятельности правоохранительных органов по борьбе с преступностью

\section{Information About the Author}

Agnessa O. Inshakova, Doctor of Sciences (Jurisprudence), Professor, Head of the Department of Civil and International Private Law (Base Department of the Southern Scientific Centre of the Russian Academy of Sciences), Volgograd State University, Prosp. Universitetsky, 100, 400062 Volgograd, Russian Federation, gimchp@volsu.ru, https://orcid.org/0000-0001-8255-8160

\section{Информация об авторе}

Агнесса Олеговна Иншакова, доктор юридических наук, профессор, заведующая кафедрой гражданского и международного частного права (базовая кафедра ЮНЦ РАН), Волгоградский государственный университет, просп. Университетский, 100, 400062 г. Волгоград, Российская Федерация, gimchp@volsu.ru, https://orcid.org/0000-0001-8255-8160 